\title{
Pengambilan Keputusan sebagai Wirausaha Muda dan Faktor Eksternal yang Memengaruhinya di Institut Bisnis dan Informatika Stikom Surabaya
}

\author{
Candraningrat \\ Institut Bisnis dan Informatika Stikom Surabaya \\ Candraningrat@ymail.com
}

\begin{abstract}
This study aimed to analyze the influence of external factors consisting of family support and Business capital to the students decision-making at the Business Faculty of the Institut Bisnis dan Informatika Stikom Surabaya. The research was conducted from 42 students were taken by the purposive sampling method which were active students who own businesses or who are interested in entrepreneurship in the future, survey method used for data gathering with instrument questionnaire and analyzed by SPSS version 21 to examine the research hypothesis. The result of multiple regression analysis showed that the variable family role and business capital is predicted to increase the student interest in entrepreneurship therefore the stated hypothesis 1 were accepted, but as partially the role of family able to increase the interest in entrepreneurship of the student, although that business capital not necessarily increase the interest of the students to entrepreneurship so the second hypothesis was rejected..
\end{abstract}

Keywords: family's' role, business capital and entrepreneur interest

\section{Pendahuluan}

Indonesia merupakan negara yang sedang berkembang dan saat ini juga masih terdapat masalah tentang kualitas sumber daya manusianya, salah satunya dalam ranah pendidikan, salah satu contohnya adalah kegiatan wajib belajar selama sembilan tahun yang telah dicanangkan oleh pemerintah masih belum diterapkan sepenuhnya oleh masyarakat, dapat dilihat pada penyerapan tenaga kerja Agustus tahun 2014 masih didominasi oleh pendidikan rendah, yaitu SD ke bawah sekitar 53 juta orang (47,07\%), dan yang ada diurutan kedua, yaitu SMA sekitar 29 juta jiwa (25.39\%). Penduduk yang berpendidikan pada perguruan tinggi hanya sekitar 8,2 juta orang atau 7,21\% (BPS, 2016).
Demikian juga dalam hal ketenagakerjaan tercatat bahwa pengangguran terbuka sejumlah 7,147 juta pada Februari 2014, dan pada bulan Agustus 2014 meningkat menjadi 7,244 juta jiwa. Hal ini menunjukkan adanya peningkatan jumlah pengangguran terbuka. Kondisi tersebut berdampak pada tumbuhnya perekonomian yang masih di bawah $8 \%$, pertumbuhan ekonomi hanya di bawah $8 \%$ belum dapat menyerap keseluruhan pengangguran yang ada. Akibat dari permasalahan di atas ialah jumlah penduduk miskin di Indonesia masih tergolong tinggi, sekitar 28,59 juta penduduk miskin pada tahun 2012 (BPS, 2016).

BPS (Badan Pusat statistik) Indonesia pada tahun 2013 mencatat sebanyak 7,4 juta pemuda yang termasuk pada usia produktif dan sedang mencari kerja. Apabila ditinjau dari 
pendidikannya sekitar 27,09\% berpendidikan sekolah dasar ke bawah, sedangkan 22,62\% masih berpendidikan SLTP, lalu sebesar 25,29\% berpendidikan SMA, dan 15,37\% berpendidikan SMK. Selain itu dapat dilihat dari lokasinya maka penyebaran pemuda di pedesaan atau perkotaan seperti berikut, sebesar 5,24 juta pemuda atau 53\% berlokasi di perkotaan sedangkan sekitar 4,2 juta orang berada di daerah pedesaan.

Dilihat dari data tentang pengangguran pada pemuda masih dalam kategori tinggi, jika tidak diperhatikan secara serius dapat mengakibatkan masalah-masalah sosial. Kemungkinan permasalahan sosial dari dampak pengangguran yang tinggi adalah penyalahgunaan narkoba oleh pemuda, tingkat kriminalitas meningkat, pergaulan bebas, premanisme, human trafficking, dan lainnya. Kondisi tersebut dapat mengganggu kegiatan pembangunan dalam segala bidang dan stabilitas nasional.

Salah satu cara dalam mengatasi pengangguran di kalangan pemuda adalah dengan program pengembangan kewirausahaan, karena wirausaha mempunyai peranan yang cukup signifikan terhadap perekonomian di Indonesia khususnya dalam mengatasi pengangguran dan mendorong terciptanya stabilitas usaha yang berkesinambungan. Menurut data BPS, sensus ekonomi (2006) pertumbuhan industri besar dan menengah sejak 2002 hingga 2006 hanya tumbuh sekitar 1.998 perusahaan atau sebesar $0.02 \%$. Sedangkan untuk industri kecil tumbuh sekitar 455.960 atau sebesar 16\%. Dari keseluruhan unit usaha manufaktur di Indonesia sebesar 1.542 juta atau sekitar 99,2\% adalah industri kecil menengah (IKM) dan industri skala rumah tangga (home industry), telah memberi kesempatan kerja cukup besar yaitu 67,3\% dari keseluruhan kesempatan kerja yang ada, dan sedangkan industri manufaktur hanya sebesar $17,8 \%$.

Dari data di atas telah memberikan gambaran begitu pentingnya kontribusi usaha kecil dan menengah dalam stabilitas ekonomi melalui peningkatan lapangan pekerja dan pemerataan pendapatan sehingga penciptaan wirausaha baru sangat diperlukan, dan pemerintah selalu mendorong pemuda baik lulusan sekolah menengah serta lulusan perguruan tinggi dibentuk menjadi seorang wirausahawan yang inovatif dan kreatif guna menjadi UKM yang kuat dan mandiri. Kasus baru-baru ini adalah perusahaan teknologi informasi yang cukup terkenal di seluruh dunia dirintis oleh seorang wirausahawan muda telah berkembang pesat di dunia. Menurut Kao (1999) negara maju seperti Amerika Serikat, Taiwan, Korea yang sangat peka terhadap pembentukan jiwa entrepreneurs (Kao, 1999).

Untuk mengubah cara pandang pemuda terhadap pekerjaan sebagai wirausaha tidaklah mudah karena pada kenyataannya banyak permasalahan yang harus dihadapi ketika menjadi seorang wirausaha karena tidak semua wirausaha bisa berjalan mulus dan selalu bisa mendatangkan uang seperti apabila mereka bekerja sebagai pegawai negeri atau bekerja di perusahaan swasta, karena itulah harus diketahui secara empiris faktor eksternal apa saja yang sebenarnya memengaruhi pengambilan keputusan seorang pemuda untuk menjadi wirausaha. Institut Bisnis dan Informatika Stikom Surabaya adalah salah satu pencetak generasi penerus bangsa yang saat ini berfokus pada mahasiswa yang memiliki jiwa wirausaha yang di mulai dari pembentukan Fakultas baru pada tahun 2014 yaitu Fakultas Ekonomi dan Bisnis, oleh karena itu penelitian ini di laksanakan di Institut Bisnis dan Informatika Stikom Surabaya. 
Selain itu, penelitian ini juga perlu dilakukan dipandang dari segi teoretis yaitu untuk lebih memperkaya dari model pengambilan keputusan individu dan model yang dilakukan oleh Cooper khususnya bagi pemuda untuk berwirausaha, sedangkan dari segi praktisnya dapat lebih mendorong pemuda untuk berwirausaha dengan berfokus pada faktor-faktor eksternal individu dan sekaligus menggeser paradigma lama bahwa lulusan sekolah atau perguruan tinggi pada era digital saat ini bukan lagi sekadar menjadi pencari kerja namun harus mampu sebagai pencipta lapangan kerja, yang dapat berguna bagi masyarakat di sekitar serta dapat memberikan andil dalam pembangunan ekonomi di Indonesia. Untuk itu, penelitian ini dilakukan dengan tujuan untuk mengetahui sampai seberapa jauh pengaruh faktor eksternal perguruan tinggi yang terdiri dari dukungan orang tua dan modal usaha berpengaruh terhadap minat wirausaha mahasiswa di Stikom Surabaya.

\section{KERANGKA TEORETIS}

\section{Pengambilan Keputusan untuk Berwirausaha}

Menurut Weihrichdan Koontz (2005) pengambilan keputusan ialah sebagai kegiatan penentuan dari sebuah pilihan langka atau tindakan dari beberapa alternatif. Sedangkan menurut George R. Terry (2003) pengambilan keputusan merupakan kegiatan memilih alternatif keputusan dari dua atau bahkan alternatif yang tersedia. Begitu juga dalam pengambilan keputusan untuk berwirausaha, pada waktu seseorang mengambil sebuah keputusan sering dihadapkan pada beberapa alternatif pilihan yang kemungkinan akan menjadi salah satu penyelesaian pada suatu masalah antara memilih menjadi seorang wirausahawan atau menja- di karyawan di sebuah perusahaan swasta maupun pemerintahan.

\section{Pilihan Menjadi Wirausawan bagi Pemuda}

Dalam buku Cashflow-Quadrant terdapat gambaran dari beberapa metode seseorang dapat memperoleh penghasilan, metode-metode tersebut terbagi menjadi empat sebagai berikut. (1) Seseorang dapat menjadi seorang pegawai, yang dimaksud pegawai adalah orang yang bekerja di sebuah perusahaan dan menjadi bawahan seseorang dengan tugas-tugas yang sudah terstruktur ataupun belum terstruktur dengan baik. (2) Pekerja lepas, yaitu seseorang bekerja di mana saja tetapi tidak berstatus tetap dalam sebuah kegiatan kerja dan kemungkinan berpindah tempat kerja dengan waktu yang tidak dapat ditentukan. (3) Pemilik usaha, yaitu seseorang mendapatkan penghasilan dari bisnis yang dijalankan sendiri tanpa tuntutan dari atasan dan dapat dikelola sendiri. (4) Penanam modal yaitu seseorang mendapatkan pendapatan dari beberapa modal yang dipinjamkan dengan syarat tertentu dalam pembagian hasil keuntungan (Kiyosaki, 2001). Beberapa model yang disajikan oleh Kiyosaki (2001) memiliki beberapa kelebihan maupun kekurangan, tetapi apabila seseorang ingin menikmati hidupnya lebih baik bekerja dengan waktu yang sedikit mungkin dan di lain waktu harus ada kegiatan lain yang dapat menghasilkan penghasilan selain gaji tetap, oleh karena itu mendapatkan penghasilan dari usaha sendiri merupakan salah satu alternatif pilihan yang patut dipertimbangkan (Drake, 2005).

Konsep tentang pemuda, dalam hal ini memiliki tiga sudut pandang, yaitu tentang batasan usia pemuda, sifat atau karakteristiknya, dan tujuan dari aktivitas kepemudaan. 
Secara biologis, yang dapat dikategorikan sebagai pemuda adalah seseorang yang berusia 15 hingga 30 tahun menurut Undang-Undang Nomor 40 Tahun 2009. Sedangkan dalam segi psikologis memiliki kematangan dalam hal berpikir dimulai sejak umur 21 tahun, sedangkan batasan pemuda sebagai generasi penerus generasi terdahulu menentukan umur pemuda sekitar 18 sampai dengan 30 tahun dan bahkan mencapai umur 40 tahun. Dari beberapa sumber di atas tingkat usia pada manusia bisa disimpulkan bahwa kategori umur bagi pemuda adalah di akhir masa remaja hingga akhir dewasa awal, atau dapat diartikan bahwa usia 18 sampai dengan 40 tahun. Berdasarkan jenjang usia dalam kategori pemuda yang berada di antara umur remaja hingga akhir awal kedewasaan, maka pemuda terdapat beberapa ciri-ciri khusus seperti berikut.

1. Dalam hal kemampuan kognitifnya sudah dapat dikatakan siap, hal ini dapat dilihat dari kemampuan seorang pemuda dalam mengetahui dan memahami suatu permasalahan, serta dapat membentuk sebuah sikap terhadap sebuah permasalahan tertentu.

2. Kesiapan emosional, hal ini dapat ditinjau dari kemampuan berpikir seorang pemuda untuk mengendalikan dan menempatkan emosi dalam menyelesaikan dari sebuah permasalahan.

3. Terlalu banyaknya masalah, hal ini dikarenakan dari rata-rata pemuda banyak memiliki ide-ide serta ide tersebut dilandasi dengan nilai-nilai ideal. Tetapi keseluruhan ide maupun keinginan tersebut dapat terealisasi dikarenakan kondisi di dalam lingkungannya sulit untuk mewujudkan nilai ideal yang diinginkan oleh seorang pemuda.

4. Keterasingan sosial, pemuda memiliki kemampuan dalam berpikir ideal serta tidak memihak apabila mendorong pemuda pada keadaan yang tidak selaras dengan lingkungan sosial.

5. Memiliki rasa tanggung jawab yang tinggi, pemuda memiliki keinginan yang tinggi guna mewujudkan segala keinginannya seringkali apapun yang dilakukan oleh seorang pemuda akan dilakukan dengan penuh tanggung jawab.

6. Lebih kreatif dan inovatif, berhubungan dengan kemampuannya menciptakan ideide atau pemikiran baru guna proses penyelesaian masalah yang sedang dihadapinya.

7. Memiliki ketergantungan kepada generasi yang lebih tua, dikarenakan keterbatasan pengalaman dari pemikiran seorang pemuda sedangkan pengalaman tersebut dimiliki oleh generasi yang lebih tua.

\section{Pengambilan Keputusan Berwirausaha}

Pada pengambilan keputusan individu dipengaruhi oleh perilaku, persepsi, motivasi, dan pembelajaran individu (Robbins, SP 2001). Selain hal tersebut, pengambilan keputusan dapat dipengaruhi pula oleh nilai dan sikap yang berubah. Model dari Cooper dalam Journal of Small Business Management (Birley, 1989) menjelaskan bahwa pengambilan keputusan seseorang untuk menjadi wirausahawan dipengaruhi oleh beberapa faktor yaitu: antecedent influence, incubator organization, dan environmental factors.

Fokus penelitian hanya pada variabelvariabel faktor eksternal yaitu peran keluarga dan sumber modal dengan alasan sebagai berikut.

1. Sumber modal dalam penelitian ini dimasukkan karena dalam pengambilan keputusan seseorang untuk menjadi wirau- 
sahawan karena dalam merintis sebuah usaha baru sangat diperlukan walaupun modal tersebut tergantung pula dengan skala bisnis yang akan dijalankan, walaupun menurut Kasali dalam pengantar buku 50 Usahawan Tahan Banting (Abe, 2000) dijelaskan bahwa modal uang merupakan sebuah pelengkap, tetapi kreativitas yang dimiliki oleh pemudalah yang diharapkan mampu menemukan sumber-sumber modal yang ada.

2. Peran dari lingkungan keluarga yang bukan seorang pebisnis ataupun yang telah memiliki bisnis juga dipertimbangkan dalam pengambilan keputusan seorang pemuda menjadi seorang wirausahawan dan perlunya mengetahui seberapa besar peran keluarga dalam aktivitas yang dilakukan oleh anaknya untuk berwirausaha.

Strategi membudayakan wirausaha di kalangan muda dalam jangka panjang lebih diarahkan untuk kesejahteraan masyarakat, mengurangi tingkat pengangguran, dan kemiskinan, untuk itu dengan segala potensi yang dimiliki pemuda akan meningkatkan kreativitas dan keberaniannya untuk bertindak termasuk dalam hal ini mengambil suatu keputusan berwirausaha.

\section{Peran Keluarga}

Peran keluarga sangat penting dalam membuat minat berwirausaha bagi para pemuda. Dalam pemberian pendidikan berwirausaha dapat diberikan sejak usia dini dalam lingkungan keluarga. Mempunyai seorang orangtua seorang wirausahawan akan lebih memberikan inspirasi kepada anak untuk menjadi seorang wirausahawan pula (Hisrich, dkk.,
2005). Tingkat fleksibilitas dan kemandirian dari seorang wirausahaan telah ada dalam diri anak seorang wirausahawan, anak juga terinspirasi dari orangtuanya karena sejak dini anak sudah terbiasa dengan pekerjaan yang ringan sampai bersifat strategis. Terlatih dan terinspirasi sehingga memengaruhi minatnya dalam berwirausaha di bidang yang sama ataupun berbeda dengan orangtua. Dari keluarga cara berpikir anak akan sendirinya terbentuk menjadi seorang wirausahawan serta berkembang dengan baik pada seseorang yang tumbuh pada lingkungan wirausaha.

Dyer (2003) juga mengamati bahwa keluarga dan kekerabatan sebagai variabel sangat banyak diabaikan dalam penelitian organisasi. Selanjutnya, Stewart (2003) berpendapat bahwa literatur tentang keluarga dan kekerabatan dalam antropologi adalah sumber pengetahuan yang bisa menguntungkan bidang penelitian bisnis keluarga. Dalam literatur jaringan kewirausahaan, dan kewirausahaan sastra pada umumnya, pengaruh keluarga dan kekerabatan diabaikan (Aldrich dan Cliff, 2003; Greve dan Salaff, 2003). Menurut Aldrich dan Cliff (2003), bahkan lebih mengejutkan ketika seseorang mempertimbangkan bahwa penelitian menunjukkan bahwa kewirausahaan sering terjadi dalam tim yang berisi anggota keluarga (Ruef et al., 2003; Aldrich et al., 2002). Aldrich et al. (2002) melaporkan bahwa 65\% dari semua tim terdiri dari hubungan pasangan/partner, ikatan keluarga lain, atau keduanya. Selanjutnya, Aldrich dan Cliff (2003) mengamati bahwa memulai bisnis seringkali merupakan respons terhadap perubahan dalam hubungan keluarga daripada penemuan rasional dalam pengembangan dan eksploitasi peluang bisnis. Dalam studi Kirkwood (2007) ditemukan bahwa orang tua memainkan peran pen- 
ting dalam penciptaan usaha baru. Pengamatan terakhir yang membuat mengabaikan keluarga bahkan lebih mengejutkan adalah penelitian yang menunjukkan bahwa anggota keluarga sering memainkan peran penting dalam mendapatkan dan memobilisasi sumber daya keuangan (Zhang et al, 2003; Steier dan Greenwood, 2000). Bygrave et al. (2003) menemukan, berdasarkan analisis mereka terhadap GEM - data yang di 29 negara, bahwa 47,9\% dari semua hubungan antara pengusaha dan investor informal kerabat. Oleh karena itu, Aldrich dan Cliff (2003) berpendapat untuk kebutuhan keluarga tertanam perspektif tentang kewirausahaan, menyiratkan bahwa peneliti menggabungkan anggota keluarga dan keluarga ke dalam model konseptual. Menurut Herdiman (2008), keluarga menjadi lingkungan pertama yang dapat menumbuhkan mental kewirausahaan anak muda.

\section{Sumber Modal}

Sarosa (2005) mendefinisikan modal sebagai jumlah uang yang ditanamkan dalam suatu usaha. Uang inilah yang akan digunakan untuk membiayai kegiatan usaha sampai dapat menghasilkan laba sendiri. Modal uang yang dapat digunakan oleh seseorang untuk memulai usaha dapat berasal dari berbagai sumber. Menurut Sarosa (2005), sumber modal dapat diperoleh dengan tiga cara, yaitu modal sendiri, meminjam, dan kerja sama dengan pihak lain. Sumber modal sendiri dapat berasal dari warisan, tabungan, dan menjual atau menggunakan aset yang kurang produktif. Meminjam dapat berasal dari perorangan dan lembaga keuangan.

Beberapa definisi dan pendapat tersebut pada prinsipnya menunjukkan hal yang sama bahwa modal dalam bentuk uang relatif tetap diperlukan oleh seseorang pada saat akan me- mulai suatu usaha betapapun kecil jumlahnya. Demikian pula terdapat beberapa alternatif sumber modal yang dapat digunakan oleh seseorang dalam memulai berwirausaha.

\section{METODE PENELITIAN}

\section{Sample dan Prosedur}

Teknik penentuan sampel dalam penelitian ini menggunakan purposive sampling, yaitu mahasiswa aktif di Institut Bisnis dan Informatika Stikom Surabaya yang memiliki usaha dan mahasiswa yang berminat usaha sendiri di kemudian hari. Menurut Winarno Surachmat (1998) dalam bukunya Metodologi Penelitian menyatakan bahwa untuk sampel kecil 30 responden telah dianggap cukup mewakili. Pengambilan data dilakukan dengan metode survei dengan instrumen kuesioner pada bulan Agustus sampai November 2016.

Dari keseluruhan responden diketahui bahwa responden berjenis kelamin pria sebesar $45,9 \%$ sedangkan responden wanita sebesar $54,1 \%$. Sedangkan dari segi jenis usaha yang telah dilakukan atau diminati ada beberapa macam usaha yaitu kuliner sebesar 33,3\%, jasa sebesar 14,3\%, teknologi informasi (startup) sebesar 9,5\%, perdagangan sebesar 26,2\%, pertambangan sebesar 2,4\%, dan fashion sebesar $16,7 \%$.

\section{Variabel Penelitian dan Pengukuran}

Variabel dalam penelitian ini mengacu pada pengukuran faktor-faktor eksternal terhadap pengambilan keputusan pemuda untuk berwirausaha. Faktor eksternal individu dalam penelitian ini adalah variabel independen yang terdiri dari peran keluarga dan sumber modal, sedangkan variabel dependen dalam penelitian 
ini ada pengambilan keputusan dalam berwirausaha. Pengukuran variabel-variabel dalam penelitian ini diukur melalui beberapa hal sebagai berikut.

1. Peran keluarga merupakan dukungan atau bahkan dorongan dari keluarga dalam pengambilan keputusan yang dilakukan oleh pemuda untuk berwirausaha. Pengukuran peran keluarga dalam penelitian ini dilakukan dengan menggunakan skala likert.

2. Sumber modal dalam penelitian ini merupakan berbagai macam sumber modal yang dapat dimanfaatkan oleh responden dan digunakan sebagai modal dalam memulai suatu usahanya. Pengukuran sumber modal dalam penelitian ini dilakukan dengan menggunakan skala likert.

3. Pengambilan keputusan berwirausaha adalah keputusan yang diambil responden untuk berniat atau menjadi berwirausaha dan dalam penelitian ini dilakukan dengan menggunakan skala likert.

Penelitian ini dilakukan secara terstruktur dan teridentifikasi yang telah dilaksanakan peneliti untuk memperoleh jawaban dari responden dari pertanyaan dalam kuesioner penelitian yang hasilnya akan dikembangkan melalui beberapa tahap pengujian sebagai pembuktian hipotesis penelitian sebelum mengambil kesimpulan penelitian. Hipotesis dalam penelitian ini yaitu, H-1: faktor eksternal peran keluarga mahasiswa Institut Bisnis dan Informatika Stikom Surabaya berpengaruh positif dalam mengambil keputusan untuk berwirausahaH dan H-2: faktor sumber modal mahasiswa Institut Bisnis dan Informatika Stikom Surabaya berpengaruh positif dalam mengambil keputusan untuk berwirausaha.
Dalam penelitian ini proses pengumpulan data menggunakan metode survey, di mana peneliti juga menggali data dari persepsi responden metode pengumpulan data dalam penelitian ini adalah dengan metode survey di mana peneliti menggali data dari persepsi responden yang dilakukan dengan wawancara dibantu dengan instrument questioner dan dilengkapi dengan wawancara terhadap responden. Berdasarkan jenis data, masalah, dan tujuan penelitian maka dalam penelitian ini menggunakan alat Analisis Regresi Berganda. Dalam proses perhitungan, data yang ada distandardisasi lebih dahulu karena skala pengukurannya berbeda.

\section{HASIL DAN PEMBAHASAN}

Dalam penelitian ini dilakukan pula pengujian validitas konstruk atau construct validity dari sebuah instrumen penelitian telah menggunakan indeks korelasi product moment Pearson, yaitu dengan cara membandingkan angka $\mathrm{r}$ "product moment" dari skor setiap item dan skor total tiap variabel dengan nilai kritis $r$ pada tingkat kepercayaan 5\% dan derajat kebebasan ( $\mathrm{df}=\mathrm{n}-2)$, yaitu sebesar 0,3. Menurut Solimun (2003), jika nilai r dari product moment lebih besar dari 0,3 dapat dinyatakan valid. Sedangkan uji reabilitas menurut Malhorta (2010) dapat dilakukan dengan metode alpha cronbach di mana disyaratkan nilai a $>0.6$.

\section{Hasil Uji Asumsi Klasik}

\section{Normalitas}

Dalam penelitian ini telah dilakukan uji normalitas dengan teknik uji Q-Q Plot dan Detrended Normal Q-Q Plot. Pengujian ini 
mengamati tentang titik penyebaran data dalam sebuah diagram atau grafik. Apabila penyebaran nilai-nilai dari data yang telah didapat mendekati garis normal, maka data tersebut dapat di katakan berdistribusi normal. Dapat dilihat pada gambar grafik di Q-Q Plot bisa dilihat pada Gambar 1 yang menunjukkan bahwa nilai-nilai pengamatan berada mendekati garis yang menunjukkan data terdistribusi normal.

Normal P-P Plot of Regression 5

Dependent Variable: $Y$

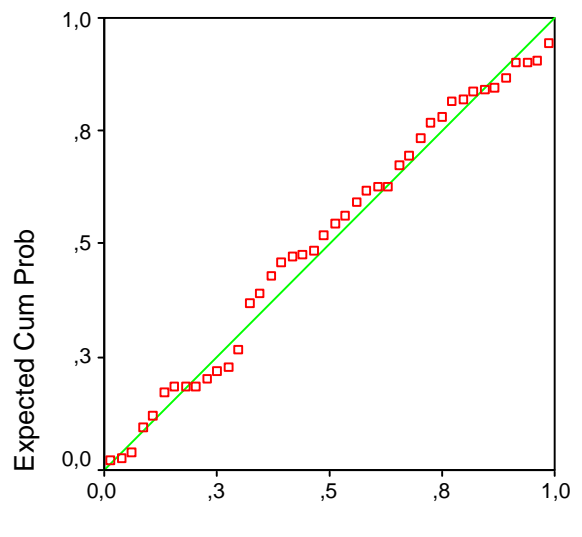

Observed Cum Prob

Gambar 1 Grafik Q-Q Plot

\section{Multikolinearitas}

Multikolinearitas digunakan untuk mengetahui apakah data yang digunakan terbebas dari auxiliary. Uji Multikolineariats dapat dilihat dari nilai tolerance dan VIF. Apabila nilai tolerance lebih dari 0,10 atau nilai VIF lebih kecil dari 10,0 maka tidak terjadi multi- kolinearitas. Sebaliknya, jika nilai tolerance lebih kecil dari 0,10 dan VIF lebih besar dari 10,0 maka terjadi multikolinearitas terhadap data yang diuji. Pada tabel 1 bisa diketahui bahwa tidak terjadi multikolinearitas karena nilai tolerance dari variabel peran keluarga dan sumber modal lebih tinggi dari standar minimal yaitu 0,10 , sedangkan nilai VIF masing-masing variabel lebih kecil dari 10,0, hal tersebut menunjukkan bahwa pada penelitian ini variabel yang telah diuji tidak terkena multikolineritas.

Tabel 1 Uji Multikolinearitas

\begin{tabular}{|c|l|l|}
\hline VARIABEL & \multicolumn{2}{|l|}{ MULTIKOLINEARITAS } \\
\hline & TOLERANCE & VIF \\
\hline Peran keluarga & 0,648 & 1,544 \\
\hline Sumber modal & 0,857 & 1,167 \\
\hline
\end{tabular}

Sumber: Pengolahan data primer

\section{Autokorelasi}

Tabel 2 menunjukkan hasil pengujian autokorelasi dengan menggunakan teknik uji Durbin-Watson.

Pada Tabel 2 dapat diketahui bahwa nilai d sebesar 1,750. Sementara dU dengan jumlah 42 responden dan dua variabel pada tabel DW diperoleh 1,6061. sehingga diperoleh persamaan sebagai berikut.

$\mathrm{dU}<\mathrm{d}<4-\mathrm{dU}=1,6061<1,750<2.3939$

Tabel 2 Durbin-Watson Autokorelasi

\begin{tabular}{|c|c|c|c|c|c|c|c|c|c|c|}
\hline \multirow[b]{2}{*}{ Model } & \multirow[b]{2}{*}{ ? } & \multirow[b]{2}{*}{$\begin{array}{c}\mathrm{R} \\
\text { Square }\end{array}$} & \multirow[b]{2}{*}{$\begin{array}{c}\text { Adjusted } \\
\text { R } \\
\text { Square }\end{array}$} & \multirow{2}{*}{\begin{tabular}{|c|} 
Std. \\
Error of \\
the \\
Estimate
\end{tabular}} & \multicolumn{5}{|c|}{ Change Statistics } & \multirow[b]{2}{*}{$\begin{array}{l}\text { Durbin- } \\
\text { Watson }\end{array}$} \\
\hline & & & & & $\begin{array}{l}\text { R Squ } \\
\text { Char }\end{array}$ & $\begin{array}{c}\mathrm{F} \\
\text { Change }\end{array}$ & df1 & df2 & $\begin{array}{c}\text { Sig. F } \\
\text { Change }\end{array}$ & \\
\hline 1 & $0,404^{a}$ & 0,163 & 0,120 & 0,49710 & 0 & 3,800 & 2 & 39 & 0,031 & 1,750 \\
\hline
\end{tabular}

Sumber: Pengolahan data primer 
Dengan melihat hasil nilai dari persamaan di atas maka bisa diartikan bahwa variabel dependen keputusan berwirausaha mahasiswa menunjukkan $\mathrm{H}_{0}$ diterima karena tidak terdapat autokorelasi. Sehingga bisa disimpulkan bahwa model ini memenuhi asumsi klasik bebas dari autokorelasi.

\section{Analisis Korelasi}

Analisis korelasi digunakan untuk mengetahui hubungan antara variabel bebas yang terdiri dari variabel peran keluarga dan modal usaha terhadap minat berwirausaha. Hasil analisis korelasi seperti yang dapat dilihat pada Tabel 3 menunjukkan bahwa hubungan antara variabel bebas X (faktor eksternal) terhadap Y (keputusan berwirausaha) adalah sebagai berikut.

Tabel 3 Koefisien Korelasi

\begin{tabular}{|c|c|c|c|c|}
\hline Model & R & R Square & $\begin{array}{c}\text { Adjusted R } \\
\text { Square }\end{array}$ & $\begin{array}{c}\text { Std. Error of } \\
\text { the Estimate }\end{array}$ \\
\hline 1 & $0,404^{\mathrm{a}}$ & 0,163 & 0,120 & 0,49710 \\
\hline
\end{tabular}

Sumber: Pengolahan data primer

Berdasarkan Tabel 3 menunjukkan hasil analisis koefisien korelasi menunjukkan angka sebesar 0,404 ini, artinya bahwa faktor eksternal yang terdiri dari peran keluarga dan sumber modal menunjukkan hubungan yang cukup dan positif, sedangkan koefisien determinasi $\mathrm{R}^{2}$ sebesar 0.163 , artinya bahwa faktor eksternal yang diwakili oleh peran keluarga dan modal mampu memberikan kontribusi pengambilan keputusan berwirausaha sebesar $16,3 \%$, sisanya $83,7 \%$ adalah unsur lain yang tidak dibahas dalam penelitian ini.

\section{Analisis Regresi}

Analisis regresi linier berganda digunakan untuk mengetahui pengaruh variabel independen yaitu variabel eksternal yang terdiri dari peran keluarga dan sumber modal terhadap variabel dependen yaitu minat berwirausaha. Adapun hasil perhitungan dari analisis regresi dapat dilihat pada Tabel 4.

Tabel 4 menunjukkan bahwa hasil analisis regresi menunjukkan persamaan sebagai berikut.

$$
\begin{aligned}
& \mathrm{Y}=\mathrm{a}+\mathrm{bx} \mathrm{x}_{1}+\mathrm{bx} \mathrm{x}_{2} \\
& \mathrm{Y}=3,234+0,274+0,091
\end{aligned}
$$

Berdasarkan persamaan regresi di atas maka dapat dijelaskan bahwa nilai konstanta (a) sebesar 3,234 menunjukkan bahwa jika kedua variabel bebas yaitu peran keluarga dan modal usaha, maka diprediksi akan meningkatkan minat wirausaha sebesar 3,234 dengan tidak dipengaruhi oleh variabel-variabel yang lain. Nilai $b_{1}$ peran orang tua $\left(\mathrm{X}_{1}\right)$ sebesar 0,274

\begin{tabular}{|c|c|c|c|c|c|c|c|c|}
\hline & \multirow[t]{2}{*}{ Model } & \multicolumn{2}{|c|}{$\begin{array}{c}\text { Unstandardized } \\
\text { Coefficients }\end{array}$} & \multirow{2}{*}{$\begin{array}{c}\text { Standardized } \\
\text { Coefficients }\end{array}$} & \multirow[t]{2}{*}{$\mathrm{t}$} & \multirow[t]{2}{*}{ Sig. } & \multicolumn{2}{|c|}{$\begin{array}{l}\text { Collinearity } \\
\text { Statistics }\end{array}$} \\
\hline & & B & Std. Error & & & & Tolerance & VIF \\
\hline \multirow[t]{3}{*}{1} & (Constant) & 3,234 & 0,473 & & 6,840 & 0,000 & & \\
\hline & Keluarga & 0,274 & 0,113 & 0,370 & 2,432 & 0,020 & 0,926 & 1,080 \\
\hline & Modal & 0,091 & 0,155 & 0,090 & 0,589 & 0,560 & 0,926 & 1,080 \\
\hline
\end{tabular}

Tabel 4 Koefisien Regresi

Sumber: Hasil Pengolahan data primer 
berarti menunjukkan apabila terjadi kenaikan pada variabel peran orang tua sebesar satu satuan maka minat wirausaha juga akan meningkat sebesar 0,274. Demikian juga untuk variabel modal usaha (X2) yaitu jika terjadi peningkatan satu satuan maka minat berwirausaha mahasiswa akan meningkat sebesar 0,091.

Berdasarkan tabel Uji T tersebut variabel $\mathrm{X} 1$ memiliki nilai signifikansi sebesar 0,20 yang berarti nilai tersebut lebih kecil dari nilai minimal error 0,05 sehingga bisa diartikan bahwa variabel keluarga secara parsial berpengaruh terhadap variabel keputusan untuk menjadi wirausahawan. Sementara itu, variabel X2 memiliki nilai signifikan sebesar 0,589, yang berarti variabel modal secara parsial tidak berpengaruh signifikan terhadap variabel pengambilan keputusan untuk menjadi wirausaha yang dikarenakan nilai signifikansinya $>0,05$.

\section{Pengujian Hipotesis}

Pengujian hipotesis di lakukan dengan menggunakan Uji F (simultan) yaitu menguji hipotesis secara bersama-sama antara variabel X1 dukungan keluarga dan variabel modal usaha X2 terhadap variabel terikat yaitu minat berwirausaha mahasiswa Institut Bisnis dan Informatika Surabaya seperti yang dapat dilihat pada Tabel 5.

Tabel 5 Anova

\begin{tabular}{|l|l|c|c|c|c|c|}
\hline \multicolumn{2}{|c|}{ Model } & $\begin{array}{c}\text { Sum of } \\
\text { Squares }\end{array}$ & Df & $\begin{array}{c}\text { Mean } \\
\text { Square }\end{array}$ & F & Sig. \\
\hline \multirow{2}{*}{1} & Regression & 1,878 & 2 & 0,939 & 3,800 & $0,031^{\mathrm{b}}$ \\
\cline { 2 - 7 } & Residual & 9,637 & 39 & 0,247 & & \\
\cline { 2 - 7 } & Total & 11,515 & 41 & & & \\
\hline
\end{tabular}

Sumber: Pengolahan data primer

Tabel 5 menunjukkan bahwa hasil perhitungan menunjukkan bahwa nilai $\mathrm{F}$ sebesar
3,800 dan nilai signifikansi sebesar 0,031 yang menunjukkan angka di bawah nilai alfa sebesar 0,05 ini dapat artinya bahwa secara simultan variabel dukungan keluarga dan modal usaha berpengaruh signifikan terhadap minat wirausaha sehingga hipotesis diterima.

Sedangkan pengujian hipotesis secara parsial dilakukan dengan menggunakan Uji $\mathrm{t}$ parsial dalam analisis regresi berganda bertujuan untuk mengetahui apakah variabel bebas (X) secara parsial (sendiri) berpengaruh signifikan terhadap variabel terikat (Y). Dasar pengambilan keputusan dalam penelitian ini menggunakan nilai signifikansi. Jika nilai Sig < 0,05 maka variabel bebas berpengaruh terhadap variabel terikat.

Seperti yang dapat dilihat pada Tabel 4 bahwa variabel $\mathrm{X}_{1}$ memiliki nilai signifikansi sebesar 0,20 yang berarti nilai tersebut lebih kecil dari nilai minimal error 0,05 sehingga bisa diartikan bahwa variabel keluarga secara parsial berpengaruh terhadap variabel keputusan untuk menjadi wirausahawan. Sementara itu, variabel X2 memiliki nilai signifikan sebesar 0,589 , yang berarti variabel modal secara parsial berpengaruh tidak signifikan terhadap variabel pengambilan keputusan untuk menjadi wirausaha yang dikarenakan nilai Signifikansinya $>0,05$.

Berdasarkan hasil pengujian dari tabel di atas diperoleh sebagai berikut.

H-1 Faktor peran keluarga mahasiswa Institut Bisnis dan Informatika Stikom Surabaya berpengaruh signifikan dalam mengambil keputusan untuk berwirausaha. $\mathrm{H}$

H-2 Faktor sumber modal mahasiswa Institut Bisnis dan Informatika Stikom Surabaya tidak berpengaruh signifikan dalam mengambil keputusan untuk berwirausaha. 


\section{Pembahasan}

Model yang dihasilkan dari analisis dalam penelitian ini menunjukkan bahwa faktor eksternal dalam hal ini terdiri dari peran keluarga $\left(\mathrm{X}_{1}\right)$ dan sumber modal $\left(\mathrm{X}_{2}\right)$ secara simultan berpengaruh signifikan terhadap minat mahasiswa untuk berwirausaha, namun secara parsial hanya variabel dukungan keluarga yang berpengaruh signifikan terhadap pengambilan keputusan untuk menjadi seorang wirausaha. Hal ini menunjukkan bahwa mahasiswa yang memiliki keluarga yang mendukung untuk berwirausaha kemungkinan besar dapat memberikan kontribusi dalam pengambilan keputusan mahasiswa untuk berwirausaha, namun tidak begitu bagi mereka yang memiliki modal usaha belum tentu memberikan kontribusi terhadap mereka untuk mengambil keputusan berwirausaha.

Minat mahasiswa untuk berwirausaha dikarenakan oleh dukungan mahasiswa ini merupakan hal yang memungkinkan karena keluarga merupakan faktor yang dominan dalam membentuk pengambilan keputusan, hal ini sesuai dengan pendapat bahwa Stewart (2003) bahwa keluarga dan kekerabatan dalam antropologi adalah sumber pengetahuan yang bisa menguntungkan bidang penelitian bisnis keluarga. Demikian juga menurut Aldrich dan Cliff (2003) dalam penelitiannya bahwa seseorang berwirausaha terjadi dalam tim yang berisi anggota keluarga (Ruef et al., 2003; Aldrich et al., 2002). Aldrich et al. (2002) melaporkan bahwa 65\% dari semua tim terdiri dari hubungan pasangan/partner, ikatan keluarga lain, atau keduanya. Selanjutnya, Aldrich dan Cliff (2003) mengamati bahwa memulai bisnis seringkali merupakan respons terhadap perubahan dalam hubungan keluarga daripada penemuan rasional dalam pengembangan dan eksploitasi peluang bisnis. Hal ini juga didukung oleh Kirkwood (2007), (Zhang et al., 2003; Steier dan Greenwood, 2000). Bygrave et al. (2003), Aldrich dan Cliff (2003), dan Herdiman (2008), keluarga menjadi lingkungan pertama yang dapat menumbuhkan mental kewirausahaan anak muda.

Lingkungan keluarga pengusaha, pengaruh untuk mengambil keputusan berwirausaha lebih kecil dibandingkan dengan dorongan dari dalam dirinya sendiri. Hal ini menunjukkan fenomena bahwa mahasiswa yang lahir dari lingkungan pengusaha mempunyai motivasi diri lebih kecil dibandingkan dengan yang bukan dari golongan keluarga pengusaha. $\mathrm{Na}$ mun demikian, peran orang tua tetap memberikan kontribusi terhadap pengambilan keputusan meskipun tidak terlalu signifikan. Fenomena yang lebih menarik adalah bahwa ternyata faktor sumber modal tidak mempunyai pengaruh terhadap keputusan berwirausaha. Hal ini menunjukkan bahwa sumber modal bukan lagi menjadi masalah. Mahasiswa beranggapan bahwa modal berusaha bisa didapatkan dari manapun. Namun berdasarkan analisis deskriptif data variabel di atas menunjukkan bahwa sebagian besar mahasiswa menggunakan modal sendiri dalam memulai berwirausaha. Mereka menggunakan tabungan pribadi dalam memulai usahanya, pun juga tidak tertarik untuk mengajukan kredit ke bank karena usia mereka yang masih belia. Sehingga dalam kasus ini, sumber modal tidak menjadi masalah berarti juga tidak memberikan pengaruh apa-apa terhadap keputusan mereka berwirausaha.

\section{Implikasi Penelitian}

Hasil penelitian mengenai pengaruh dukungan keluarga dan modal usaha terhadap 
pengambilan keputusan mahasiswa untuk berwirausaha akan memberikan implikasi bahwa dalam memberikan pendidikan dan motivasi berwirausaha bagi mahasiswa untuk menekankan pentingnya dukungan keluarga dalam mewujudkan pemerintah khususnya Dirjen Pendidikan Tinggi dalam mengembangkan program kewirausahaan di perguruan tinggi, mengingat keterbatasan lapangan kerja dan semakin meningkatnya jumlah pengangguran berpendidikan tinggi. Dengan hasil penelitian ini maka para pendidik mendapatkan gambaran bagaimana cara memotivasi dan mendidik mahasiswa untuk berminat menekuni wirausaha setelah mereka lulus dari perguruan tinggi.

Penelitian ini memiliki beberapa keterbatasan yaitu belum mampu menampilkan semua variabel yang mungkin terkait dengan kemajuan usaha responden yang kemungkinan juga disebabkan oleh variabel-variabel lain yang tidak termasuk dalam penelitian ini. Peneliti juga menyadari bahwa jumlah sampel kurang memenuhi ketentuan, sehingga harus dilakukan penggantian teknik analisis dalam mengolah data. Oleh karena itu, hendaknya penelitian selanjutnya dapat menggunakan sampel yang sesuai dan memenuhi ketentuan.

Berdasarkan hasil temuan di atas maka dapat direkomendasikan bahwa penyusunan kurikulum pendidikan wirausaha bagi mahasiswa di perguruan tinggi hendaknya melibatkan pengusaha dalam pembelajarannya, tidak hanya dilakukan secara teori namun juga praktik dengan memperhatikan minat bidang usaha yang di inginkan mahasiswa terlebih bagi mereka yang keluarganya sudah memiliki usaha akan sangat berpengaruh terhadap minat mereka berwirausaha sebagaimana hasil penelitian ini bahwa dukungan keluarga sangat berpenga- ruh signifikan terhadap pengambilan keputusan mereka.

\section{DAFTAR PUSTAKA}

Abe, George. 2000. Residential Broadband, second edition. Cisco Press, Indianapolis.

Aldrich, H.E., Carter, 0N.M., and Ruef, M. 2002. "With very little help from their friends: gender and relational composition of nascent entrepreneurs' startup teams”, in Bygrave, W.D., Brush, C.G., Davidsson, P.et al. (Eds), Frontiers of Entrepreneurship Research 2002, Center for Entrepreneurship Research, Babson College, Wellesley, MA, pp. 15669.

Aldrich, H.E. and Cliff, J.E. 2003. "The pervasive effects of family on entrepreneurship: toward a family embeddedness perspective". Journal of Business Venturing, Vol. 18, pp. 573-96.

Birley, S. 1989. 'The Start-up, in P. Burns and J. Dewhurst (eds). Small Business and Entrepreneurship. London: Macmillan, pp. 9-27.

Bygrave, W.D., Hay, M. and Reynolds, P.D. 2003. "Executive forum: a study of informal investing in 29 nations composing the Global Entrepreneurship Monitor". Venture Capital, Vol. 5 No. 2, pp. 101-16.

Drake R.L, Wayne V., Mitchell A.W.M. 2005. Gray's anatomy for students. Philadelphia: Churcill Livingstone.

Dyer, G. 2003. "The family: the missing variable in organizational research", Entrepreneurship Theory and Practice, Vol. 27 No. 4, pp. 401-16. 
George R. Terry. 2003. Prinsip-Prinsip Manajemen. PT Bumi Aksara.

Greve, A. and Salaff, J.W. 2003, "Social networks and entrepreneurship". Entrepreneurship Theory and Practice, Vol. 28 No. 1, pp. 1-22.

Herdiman, F.S. 2008. Wirausahawan Muda Mulai dari Lingkungan Keluarga, (http:/ /jurnal nasional.com/media, diakses 12 april 2016) .

Hisrich, R.D. et al. 2005. Entrepreneurship, $6^{\text {th }}$ ed. McGraw-HillIrwin, New York.

Kao, J.J. 1989. Entrepreneurship Creativity, and Organization. Brasil: Editora Prentice-Hall.

Kirkwood, Jodyanne. 2007. "Igniting the entrepreneurial spirit: is the role parents play gendered?" International Journal of Entrepreneurial Behavior \& $R e$ search, Vol. 13 Iss: 1, pp.39-59.

Kiyosaki Robert T. dan Lechter Sharon L. 2001. Business School. Jakarta: Gramedia Pustaka Utama.

Malhotra, N.K. 2010. Marketing research an applied orientation. $6^{\text {th }}$ edition. New Jersey: Pearson Education Inc.

Robbins, Stephen P. 2001. Perilaku Organisasi, Edisi 8. Prentice Hall, Jakarta.

Sarosa, P. 2005. Kiat praktis membuka usaha. Becoming young entrepreneur: Dream big start small, act now! Panduan praktis \& motivasional bagi kaum muda dan mahasiswa. Jakarta: PT Elex Media Komputindo.

Solesvik, Z, Marina. 2013. Entrepreneurial motivations and intentions: investigating the role of education major. Educa- tion and Training, Vol. 55 No. 3, 2013 pp. 253-271.

Solimun. 2002. Multivariate Analysis Structural Equation Modelling (SEM) Lisrel dan Amos. Fakultas MIPA, Universitas Brawijaya.

Steier, L. and Greenwood, R. 2000, "Entrepreneurship and the evolution of angel financial networks". Organization Studies, Vol. 21 No. 1, pp. 163-92.

Stewart, A. 2003, "Help one another, use one another: toward an anthropology of family business". Entrepreneurship Theory \& Practice, Vol. 27 No. 4, pp. 38396.

Weihrich dan Koontz. 2005. Management: A Global Perspective. McGraw-Hill Education.

Wu, S. \& Wu, L. 2008. The Impact of Higher Education on Entrepreneurial Intentions of University Students in China. Journal of Small Business and Enterprise Development, 15(4):752-774.

Zhang, J., Wong, P.-K. and Soh, P.-H. 2003. "Network ties, prior knowledge and resource acquisition by high-tech entrepreneurs". Paper presented at the Academy of Management Conference, Seattle, WA, August 1-6.

BPS Pusat. 2006. Sensus Ekonomi

BPS Pusat, 2013

BPS Pusat, 2016

.BPS Kota Surabaya. 2010. Rpjmd Kota Surabaya 2010-2015, II - 39

.UU No. 40 Tahun 2009 tentang Kepemudaan. 